\title{
EFFECT OF A RATION LOW IN FAT SOLUBLE "A" ON THE TISSUES OF RATS *
}

\author{
MARGUERITE DAVIS AND JULIA OUTHOUSE \\ MADISON, WIS.
}

It is an established fact that the fat soluble vitamin is necessary in the ration. Drummond ${ }^{1}$ reported a lowered resistance to infection in rats deprived of this vitamin. He found, however, no specific pathologic change on gross examination of grown or half grown rats. Emmett ${ }^{2}$ states also that in a histologic examination of rats fed a ration deficient in the fat soluble vitamin he found the tissues normal. $\mathrm{He}$ does not give the age of the animals.

On the other hand, Tozer ${ }^{8}$ found that young guinea-pigs on a ration deficient in the fat soluble vitamin, even with an excess of the antiscorbutic vitamin, develop enlargements of the costochondral junctions very similar to the beadings of scurvy.

M. Mellanby, ${ }^{4}$ who worked with puppies, found that the fat soluble vitamin controlled the calcification of the teeth. With a ration of white bread and 200 c.c. skimmed milk daily, the shedding of the deciduous teeth was retarded, the development of the permanent dentition was delayed, the arrangement of the teeth in the jaws was poor, and the calcium content of the teeth was subnormal. The teeth of the more rapidly growing puppies were worse. If the puppy was over 3 months old when put on the ration, the teeth were not affected to any degree.

E. Mellanby ${ }^{5}$ has shown that the fat soluble vitamin is largely responsible for the calcification of bone. With the bread and skimmed milk ration, puppies developed a beading of the ribs. This is more marked in puppies one month old than in those 6 weeks old. After eight weeks they failed to develop the beaded rib. This lesion appears to be outgrown in time, and resembles the condition of rickets in children.

The two lines of investigation which we have followed are: (1) a long time experiment with a ration low in the fat soluble vitamin but satisfactory in other respects; (2) an experiment with young animals on a ration low in the fat soluble vitamin. We are not as yet ready to report the results of the second experiment.

* Received for publication, Nov. 3, 1920.

* From the Home Economics Laboratory, University of Wisconsin.

1. Drummond: Biochem. J. 13:95, 1919.

2. Emmett: J. Biol. Chem. (Proceedings) 41: 1iii, 1920.

3. Tozer: Quoted by Delf, Biochem. J. 14:212, 1920.

4. Mellanby, M.: Lancet 2:767, 1918.

5. Mellanby, E.: Lancet 1:407, 1918. 
It was necessary to choose a ration which was eaten readily, for there are marked pathologic changes in inanition. Jackson ${ }^{6}$ found that a limited amount of whole wheat bread and whole milk produced definite changes in the suprarenal of rats. McCarrison ${ }^{7}$ reports a profound effect of inanition on the gastro-intestinal tract of monkeys which had refused to eat a diet of autoclaved rice. In fowls he found hypertrophy of the suprarenal with an increased amount of epinephrin. Other organs were greatly atrophied.

TABLE 1.-Comparison of Weights of Organs of Donaldson's and Authors' Experiment Animals

\begin{tabular}{|c|c|c|c|c|c|}
\hline & Age & $\begin{array}{c}\text { Body } \\
\text { Weight, } \\
\text { Gm. }\end{array}$ & $\begin{array}{c}\text { Two } \\
\text { Kidneys, } \\
\text { Gm. }\end{array}$ & $\begin{array}{l}\text { Spleen, } \\
\text { Gm. }\end{array}$ & $\begin{array}{c}\text { Testes, } \\
\text { Gm. }\end{array}$ \\
\hline 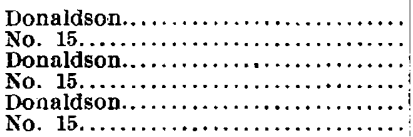 & $\begin{array}{l}\dddot{1 i 4} \\
\ddot{1 i 4} \\
\ddot{1 i 4}\end{array}$ & $\begin{array}{l}204.3 \\
203.0 \\
178.1 \\
178.0 \\
175.0 \\
174.0\end{array}$ & $\begin{array}{l}1.74 \\
2.0 \\
1.544 \\
1.3 \\
1.521 \\
1.6\end{array}$ & $\begin{array}{l}0.545 \\
1.0^{*} \\
0.479 \\
0.65 \\
0.471 \\
0.9\end{array}$ & $\begin{array}{l}2.203 \\
2.8 \\
2.030 \\
2.5 \\
2.007 \\
1.0+\end{array}$ \\
\hline
\end{tabular}

* Enlarged spleens are common in stock rats.

t Only one testes found.

TABLE 2.-Growth of Second Generation Born on the Ration

\begin{tabular}{|c|c|c|c|}
\hline $\begin{array}{l}\text { Serial No. of } \\
\text { Litter }\end{array}$ & $\begin{array}{l}\text { Age at Death, } \\
\text { Days }\end{array}$ & $\underset{G m .}{\text { Maximum }}$ Weight, & $\begin{array}{l}\text { Normal Weight, } \\
\text { for Age, Gm. }\end{array}$ \\
\hline 26 & $\begin{array}{c}101 \\
60 \\
50 \\
100 \\
70 \\
60 \\
40 \\
75 \\
70 \\
90 \\
50 \\
50 \\
\text { Discontinued at }\end{array}$ & $\begin{array}{l}89 \\
26 \\
32 \\
98 \\
51 \\
40 \\
20 \\
64 \\
42 \\
71 \\
22 \\
32\end{array}$ & $\begin{array}{l}165 \\
777 \\
59 \\
1165 \\
104 \\
80 \\
43 \\
118 \\
98 \\
150 \\
59 \\
25\end{array}$ \\
\hline & $\begin{array}{l}\text { Discontinued at } \\
\quad 25 \text { days }\end{array}$ & 35 & 25 \\
\hline
\end{tabular}

Rats were employed because the span of life is shorter and we desired to continue the ration through as many generations as possible. The ration consisted of crushed oats, polished rice and skimmed milk ad libitum, and a limited amount of cooked potato and egg white. On this ration, the half grown males grew at from 80 to 90 per cent. of the normal rate for three months. After a period of maintenance, they became emaciated and died. None lived longer than eight months.

Most of the females reared one litter and a few reared two litters on the ration. All but three of the litters were born in the first two

6. Jackson: Am. J. Anat. 21:321, 1917.

7. McCarrison: Indian J. M. Res. 7:269, 1919. 
months. A second litter of four young was born when the mother had been 148 days on the ration.

One of the four was a female. She reared a litter of two young. She was 135 days old at parturition, which made 283 days since the beginning of the experiment. When the young were twenty-five days old, they were discontinued. This made 308 consecutive days for the three generations.

Of the twenty-three females born and continued on the ration, seven produced litters. Only two of these litters were reared. There were eleven young in one litter. They were born when the mother was 131 days old and 144 days after the original rats were put on the ration. Two of the eleven lived 101 days, which made a total of 285 days of the experiment.

Distended abdomens were conspicuous in all of the young born on the ration. In some cases this disappeared after four or five months. Xerophthalmia, which Osborne and Mendel ${ }^{8}$ and McCollum and Simmonds ${ }^{9}$ reported in the absence of the fat soluble vitamin, appeared at from four to five months in the rats born on the ration. In less than 200 days, all of the animals had either died or were chloroformed in an emaciated condition. Three rats born on the ration were killed when they were still growing and in good condition. The testes, kidneys and spleen were weighed, and the weights were compared with those given by Donaldson ${ }^{10}$ for rats of the same weight. Table 1 shows that these organs are of about normal weight.

In the litter of eleven young of the second generation born on the ration, in addition to the distended abdomen and xerophthalmia, small hemorrhagic spots appeared on the tails, and when the rats were about 30 days old the ends of the tails dropped off. The eyes were pale and a blood count showed from 4,000,000 to 5,000,000 red blood cells in contrast to a normal count of 8,000,000. Table 2 gives the growth in this generation.

A postmortem examination of the rats put on the ration, as well as of those born on the ration, showed the stomach and intestines filled with gas, the intestines dull and brown, and no intraperitoneal fat visible.

Necropsy of the second generation born on the ration revealed very marked anemia. The lungs were white and the liver and kidneys were sand color. The bones were very fragile. There was no apparent beading of the ribs.

A histologic examination was made on rats from most of the litters. The organs examined were: heart, spleen, liver, lung, pancreas, kidney

8. Osborn and Mendel: J. Biol. Chem. 16:431, 1913.

9. McCollum and Simonds: J. Biol. Chem. 32:347, 1917.

10. Donaldson: Memoirs of Wistar Institute of Anat. and Biol., No. 6, 1915. 
and testes. The tissues were removed immediately at necropsy and fixed in Zenker's fluid, embedded in paraffin, cleared in xylol, and stained with hematoxylin and eosin. This stain gives only the marked differences. Differential stains were not used.

TABLE 3.-Results of Histologic Examination of Organs

\begin{tabular}{|c|c|c|c|c|c|c|c|c|}
\hline $\begin{array}{l}\text { Lot } \\
\text { No. }\end{array}$ & $\begin{array}{c}\text { Animal } \\
\text { No. }\end{array}$ & $\left|\begin{array}{l}\text { Days on } \\
\text { Ration }\end{array}\right|$ & Kidney & Spleen & Lung & Heart & $\begin{array}{l}\text { Pan- } \\
\text { creas }\end{array}$ & Liver \\
\hline 7 & 3 & 227 & Gloudy swelling & $\begin{array}{c}\text { Dilated venous } \\
\text { sinuses }\end{array}$ & * & * & Normal & Normal \\
\hline 8 & 4 & 227 & Cloudy swelling & $\begin{array}{l}\text { Dilated venous } \\
\text { sinuses }\end{array}$ & .. & $*$ & Normal & Normal \\
\hline 5 & 6 & 217 & $\begin{array}{c}\text { Slight conges- } \\
\text { tion }\end{array}$ & Congestion & $\begin{array}{c}\text { Conges- } \\
\text { tion }\end{array}$ & Normal & Normal & Normal \\
\hline 7 & 6 & 217 & $\begin{array}{l}\text { Albuminous pre- } \\
\text { cipitation in } \\
\text { tubules, slight } \\
\text { congestion }\end{array}$ & * & * & Normal & Normal & Normal \\
\hline 9 & 9f & 93 & $\begin{array}{l}\text { Slight conges- } \\
\text { tion, albuminous } \\
\text { precipltation } \\
\text { in tubules }\end{array}$ & Congestion & Normal & Normal & * & * \\
\hline \multirow[t]{3}{*}{15} & $10 t$ & 115 & Cloudy swelling & n.......... & Normal & $\begin{array}{l}\text { Slight } \\
\text { atrophy } \\
\text { of paren- } \\
\text { chyma }\end{array}$ & Normal & Norinal \\
\hline & 12 & 115 & $\begin{array}{l}\text { Cloudy swelling, } \\
\text { albumin in } \\
\text { tubules }\end{array}$ & $\begin{array}{l}\text { Congestion, } \\
\text { dilated venous } \\
\text { sinuses }\end{array}$ & * & * & Normal & .. \\
\hline & 14 & 181 & $\begin{array}{c}\text { Cloudy swelling, } \\
\text { albumin in } \\
\text { tubules }\end{array}$ & $\begin{array}{l}\text { Congestion, } \\
\text { dilated venous } \\
\text { sinuses }\end{array}$ & * & * & Normal & Normal \\
\hline \multirow[t]{3}{*}{18} & $25 \dagger$ & 178 & $\begin{array}{c}\text { Cloudy swelling, } \\
\text { congestion }\end{array}$ & $\begin{array}{c}\text { Extreme } \\
\text { congestion }\end{array}$ & Normal & Normal & Normal & Normal \\
\hline & $26+$ & 178 & $\begin{array}{l}\text { Cloudy swelling, } \\
\text { albumin in } \\
\text { tubules }\end{array}$ & * & * & Normal & Normal & $*$ \\
\hline & 27 & 178 & $\begin{array}{c}\text { Cloudy swelling, } \\
\text { albumin in } \\
\text { tubules }\end{array}$ & $\begin{array}{l}\text { Dilated venous } \\
\text { sinuses, slight } \\
\text { destruetion } \\
\text { of tissue }\end{array}$ & $*$ & Normal & * & * \\
\hline \multirow[t]{2}{*}{26} & $30 t$ & 70 & $\begin{array}{l}\text { Extreme cloudy } \\
\text { swelling, cells } \\
\text { of tubules } \\
\text { skeletonized }\end{array}$ & Congestion & $\begin{array}{c}\text { Broncho- } \\
\text { pneu- } \\
\text { monia }\end{array}$ & Normal & $\begin{array}{l}\text { Nuclei } \\
\text { indis- } \\
\text { tinct }\end{array}$ & $\begin{array}{l}\text { Absence } \\
\text { of red } \\
\text { blood } \\
\text { cells }\end{array}$ \\
\hline & $31 \dagger$ & 70 & $\begin{array}{l}\text { Extreme cloudy } \\
\text { swelling, cells } \\
\text { of tubules } \\
\text { skeletonfzed, } \\
\text { glomerull } \\
\text { shrunken }\end{array}$ & Congestion & $\begin{array}{c}\text { Broncho- } \\
\text { pneu- } \\
\text { monia }\end{array}$ & Normal & Normal & $\begin{array}{c}\text { Absence } \\
\text { of red } \\
\text { blood } \\
\text { cells }\end{array}$ \\
\hline
\end{tabular}

* Not examined.

+ Testes in Animals No. 9, 10, 25, 26, 30 and 31 were normal; testes of other animals not examined.

The examination showed that there were very few changes in the tissues on this ration. The heart, pancreas, liver and testes remained normal in most cases. Slight changes were found in the kidney and spleen. Congestion and chronic inflammation was frequently found, 
indicating, in all probability, a secondary infection, although an effort was made to discard without microscopic examination all those which gave evidence of infections of the respiratory tract.

Liver: The liver appeared to be normal in all cases. Necrotic and degenerative changes were absent. In Lot 26 there was a total absence of red blood cells. Otherwise the structure was normal.

Spleen: The spleen showed very slight changes. There was congestion with frequent dilation of venous sinuses. In some the congestion was so marked as to mask the structure. Necrosis or degeneration of splenic reticulum was not observed. There seemed to be no relationship between the degree of congestion and the duration of the experiment.

Kidney: The main finding in the kidney was cloudy swelling of the parenchyma of the collecting tubules. This was more marked in the tissues of the second generation born on the ration. An albuminous precipitate was present in the tubules of some. Congestion also was found. The kidneys of Lot 26 were most affected. In places the cells of the tubules appeared skeletonized, and the glomerular tufts were slightly shrunken.

The results of the histologic examination are shown in Table 3. Lots $5,6,7,8$ and 9 were fed on the ration when half grown. Lots $15,16,17,18$ and 19 were born on the ration. Lot 26 was born from Lot 15. 